\title{
Article \\ Efficiency of Microencapsulation of Proteolytic Enzymes
}

\author{
Sergey L. Tikhonov ${ }^{1}$, Natalya V. Tikhonova ${ }^{1}$, Leonid S. Kudryashov ${ }^{2}$, Olga A. Kudryashova ${ }^{3}$, \\ Nadezhda V. Moskovenko ${ }^{1, *(D)}$ and Irina N. Tretyakova ${ }^{1}$ \\ 1 Institute of Management, Entrepreneurship and Engineering, Ural State Economic University, \\ 8 Marta St/Narodnoy Voli, 62/45, 620144 Yekaterinburg, Russia; tihonov75@bk.ru (S.L.T.); \\ turizm@usue.ru (N.V.T.); kafedra613@mail.ru (I.N.T.) \\ 2 V.M. Gorbatov Federal Research Center for Food Systems of Russian Academy of Sciences, \\ 109316 Moscow, Russia; lskudriashov@yandex.ru \\ 3 All-Russian Scientific Research Institute of Poultry Processing Industry-Branch of FSC ARRTPI \\ RAS (ARSRIPPI), Solnechnogorsk District, Rzhavka District Center, 141552 Moscow, Russia; std@vniipp.ru \\ * Correspondence: mik_ml@mail.ru
}

Citation: Tikhonov, S.L.

Tikhonova, N.V.; Kudryashov, L.S.; Kudryashova, O.A.;

Moskovenko, N.V.; Tretyakova, I.N Efficiency of Microencapsulation of Proteolytic Enzymes. Catalysts 2021, 11, 1270. https://doi.org/10.3390/ catal11111270

Academic Editor: Maria H. L. Ribeiro

Received: 31 August 2021

Accepted: 12 October 2021

Published: 21 October 202

Publisher's Note: MDPI stays neutral with regard to jurisdictional claims in published maps and institutional affiliations.

Copyright: (c) 2021 by the authors. Licensee MDPI, Basel, Switzerland. This article is an open access article distributed under the terms and conditions of the Creative Commons Attribution (CC BY) license (https:// creativecommons.org/licenses/by/ $4.0 /)$

\begin{abstract}
Currently, special attention is paid to the study of the effectiveness of the immobilization method-microencapsulation. The aim of the research is to obtain a complex enzyme preparation from pepsin and papain by sequential microencapsulation of enzymes in a pseudo-boiling layer and to evaluate its tenderizing effect on pork. The objects of research were enzymes: pepsin and papain, which were microencapsulated in a protective coating of maltodextrin. It was found that the biocatalytic activity of the complex enzyme preparation is higher than that of pure enzymes. Microencapsulation allows maintaining the high proteolytic activity of enzymes for a long storage period. It has been shown that the thickness of the protective layer during microencapsulation of pepsin and papain in the pseudo-boiling layer of maltodextrin should be in the range of 4-6 microns. During the research, the physicochemical properties of pork were studied depending on the duration of fermentation. It was found that the maximum activity of immobilized enzymes is shifted to the alkaline side. Pork salting with the use of a microencapsulated enzyme preparation in the brine increases the water-binding capacity of proteins to a greater extent in comparison with brine with pure enzymes. The presented data show the high efficiency of sequential microencapsulation of the enzyme pepsin and then papain into a protective layer of maltodextrin in order to preserve their activity during storage.
\end{abstract}

Keywords: enzyme preparation; papain; pepsin; maltodextrin; pseudo-boiling layer; pork; microencapsulation

\section{Introduction}

More than $60 \%$ of the world market of protease-acting enzyme preparations is used in the food industry [1]. The improvement of methods for isolation, purification and identification of enzymes contributes to the expansion of the range of proteases [2-4]. Proteolytic enzymes are used both in the processing of by-products of meat, dairy and poultry processing industry, and when developing food products. According to Dwivedi et al. [5], purified extracellular keratinase obtained from Aspergillus (Aspergillus sp. DHE7) shows its activity against casein, bovine serum albumin, gelatin, to feathers and wool in the $\mathrm{pH}$ range of 7-11 at a temperature of $37-70^{\circ} \mathrm{C}$. The paper of El-Ghonemy and Ali [6] provides data on the study of the alkaline protease Nocardiopsis dassonvillei subsp. Albirubide, and the proteolytic effect of the enzyme preparation on blood proteins, gelatin and keratin was established.

To increase the tenderness and moisture-binding ability of cattle meat [7], used protease isolated from ginger powder. It is shown that this enzyme helps to increase collagen solubility. 
The processing of meat raw materials with proteolytic enzymes is still an important area of the meat industry. Thus, to obtain hydrolyzed forms of raw meat with a high collagen content, enzyme preparations of alkaline proteases Bacilluslicheniformis and Acremoniumchrysogenum are actively used. The criteria for the selection of proteases in such cases are often the optima of the action of the enzymes used, which should correlate with the main technological parameters of meat production $(\mathrm{pH}$, temperature) [8].

Enzymatic modification of raw meat with a high content of connective tissue is a promising direction in the meat industry, allowing to improve its properties and expand the possibilities of use. To obtain hydrolyzed forms of such raw materials, enzyme preparations of microbial origin are actively used. The recombinant Pichiapastoris strain, the producer of the recombinant peptidase M9 Aeromonassalmonicida, has a specific enzymatic activity against collagen, the main component of the connective tissue of meat. The resulting recombinant peptidase $\mathrm{M} 9$ can be used as a softening enzyme for meat raw materials with an increased content of connective tissue [9].

To improve the structural and mechanical characteristics of beef products and chicken, Ribeiro et al. [10] offer to use the composition of two enzymes-papain ( $0.2 \%)$ and transglutamine $(1 \%)$. It has been established that for both types of meat raw materials, the combination of these two enzymes contributes to improving the consistency of finished products.

The sequence of the native gene of the Aeromonassalmonicida M9 peptidase was successfully cloned. In the article, San et al. describes a method for obtaining recombinant aspartate proteinase from Rhizomucormiehei expressed in Pichiapastoris, which can be used for softening raw meat. The resulting enzyme had a high total proteolytic activity $(3480.4 \mathrm{U} / \mathrm{mL})$. The effective use of recombinant aspartate protease in the softening of pork, in which there is relatively little connective tissue, was noted. It can be assumed that the softening of meat in this case is achieved due to the degradation of muscle proteins, and not connective tissue proteins [11].

The problem of using the original producer strains as producers of specific peptidases is their production of a whole pool of enzymes close in molecular weight to the desired one, which makes purification and production of the desired enzyme impossible. The technology of obtaining highly purified collagenase Clostridiumhystolyticum, which forms the basis of a medical preparation for the treatment of Dupuytren's contracture, has been patented abroad [12]. The enzyme is distinguished by a high degree of purification, but the cost of its production makes it impossible to use this technology in the food industry.

It is known that one of the promising ways to preserve the activity of biologically active substances, including enzyme preparations, is immobilization by attaching them to an inert insoluble polymer matrix. The shell is impervious to the enzyme and highmolecular compounds located in the external environment; at the same time, it allows low-molecular substances to freely diffuse through it. One of the promising methods of immobilization is microencapsulation. For encapsulating various biologically active compounds, carbohydrates are used as wall materials or carrier. Special attention is paid to studying the effect of the process conditions on the effectiveness of encapsulation and the size of particles of encapsulated biologically active substances [13-16].

The authors Homayouni-Rad et al. [17] investigated the viability of Lactobacillus casei in microencapsulated forms with Alyssumhomolocarpum (AHSM) seeds and inulin, as well as in the form of free cells (not encapsulated) under simulated conditions of the gastrointestinal tract. Spray drying method was used for microencapsulation. The mixture of inulin and AHSM provided better preservation of bacteria after spray drying. Research results have shown that AHSM, as a new gum, and inulin, as a prebiotic ingredient, can provide suitable conditions for the viability of $L$. casei under the high heat conditions of the spray dryer and adverse effects of gastric and bile solutions.

The effectiveness of the immobilization method for maintaining a high microbial population and extending the shelf life of the bioorganic fertilizer was confirmed in the study of Stella et al. [18]. Four gram-negative bacterial strains with beneficial properties 
such as phosphorus solubilization, indoleacetic acid formation, siderophore formation and nitrogen fixation were immobilized in a modified alginate solution and included with compost, organic fertilizers and mineral fertilizers. The results of field studies have shown the effectiveness of immobilized bioorganic fertilizer in increasing the weight of cabbage heads compared to organic fertilizer. This is also the first report on the shelf life of immobilized bacterial cells included in organic and mineral fertilizers.

In the study of Bahgat et al. [19], the potential use of a multi-component synbiotic microcapsule in the production of yoghurt has been presented. The results showed the viability of bifidobacteria culture was enhanced by the application of the double-coated microcapsule compared to the free one. This increase was further enhanced when inulin was included either in free form or in nanoparticle form. It was concluded that both the double-coated layer covering the multi-component microcapsule and the trapped inulin significantly increase the vitality of the encapsulated Bifidobacteria culture in yogurt during storage.

Chitinases are chitinous glycosyl hydrolases that can be used in a variety of biotechnological applications. In the study of Shaymaa et al. [20], the exochitinase produced by the Alternaria sp. Sha was immobilized on carrageenan-guar gum gel beads with an immobilization yield of $43 \%$, increased to $100 \%$ by statistical optimization using a central composite design. The activity of the immobilized enzyme was optimized for the effect of temperature, $\mathrm{pH}$ and substrate concentration, which indicates that the immobilized enzyme was optimally active at $60^{\circ} \mathrm{C}$ and $\mathrm{pH} 5$. In addition, the immobilized enzyme showed high thermal and operational stability, it retained more than $90 \%$ of its activity after $2 \mathrm{~h}$ at $65{ }^{\circ} \mathrm{C}$ and retained $100 \%$ of its activity for more than 15 cycles, and also retained full activity at $4{ }^{\circ} \mathrm{C}$ for more than one month. Finally, the immobilized enzyme was successfully used to directly hydrolyze crab chitin and obtain chitooligosaccharides.

In order to increase the mechanical stability of $\beta$-D-galactosidase ( $\beta$ gal) enzymes for microencapsulation after treatment with polyethyleneimine and glutaraldehyde, carrageenancalcium pectin (Car-CPT) granules were used as a protective coating. After treatment, the enzymes acquired a higher percentage of recovery of activity and shifted the optimal temperature to a higher range $\left(55-65^{\circ} \mathrm{C}\right)$. The stability of immobilized enzymes during storage also increased [21].

In study of Weber et al. [22], chitosan beads cross-linked with glutaraldehyde were obtained and characterized to immobilize Burkholderiacepacia lipase (BCL, 23,000 U/g). The time of cross-linking and the concentration of glutaraldehyde were estimated. The immobilized BCL was used to transesterify geraniol with vinyl acetate in an organic medium. Lipase (BCL) remained stable and active under mild reaction conditions $\left(35^{\circ} \mathrm{C}\right.$ for $72 \mathrm{~h}$ reaction). Immobilized lipase has shown great stability in non-polar solvents $(\log P>3.0)$, which allows it to be reused, with a gradual loss of catalytic activity within 120 days of storage. The results showed that this immobilization process is efficient and low in cost.

The ability of polypyrroles to assimilate enzymes opens up new possibilities for enzyme immobilization. Surfactants sodium dodecyl sulfate (SDS), CTAB, and TWIN-80 were used as templates for the preparation of spherical polypyrrole particles by microemulsion polymerization. Diastase alpha-amylase extracted from malt is a model enzyme for our research. After 15 cycles of repeated use, the immobilized enzymes retained almost $50 \%$ of their original activity. Thermal and storage stability exhibited by immobilized enzymes provide a contribution from carriers for future biochemical applications [23].

The laccase enzyme from Polyporus durus ATCC 26726 was immobilized on nanoporous zeolite-X (ZX) with an immobilization yield of $83 \%$. The immobilization process protected the laccase from changes in $\mathrm{pH}$ and temperature. The activation energy was reduced after immobilization. Compared to the free enzyme, the immobilized enzyme showed a higher $\mathrm{K} \mathrm{m}$ and a lower maximum $\mathrm{V}$. Immobilized laccase showed higher half-lives ( $\mathrm{t} 1 / 2)$, a higher decimal contraction time (D-value) and a lower deactivation rate constant $(\mathrm{Kd})$ in the temperature range $50-70{ }^{\circ} \mathrm{C}$. In addition, there was an increase in the number of 
revolutions (cat) after immobilization. Immobilized laccase can discolor two dyes and two synthetic waste-water solutions. It retained 100\% activity against AB 225 after 7 successive bleaching cycles and could be used 11 times with a $48 \%$ loss of activity [24].

An almost quantitative $(98 \%)$ immobilization was obtained from the crude extract of the soybean seed coat. After $4 \mathrm{~h}$ at $70{ }^{\circ} \mathrm{C}$, the activity of free soybean hull areas (SBU) was $50 \%$ lower than that of the immobilized enzyme. The $\mathrm{pH}$ of maximum activity shifted from 7 to 5 after immobilization, which makes it possible to use it in processes performed at acidic $\mathrm{pH}$ ( $\mathrm{pH} 3-5)$. Immobilization led to an increase in the optimal temperature for activity from $65^{\circ} \mathrm{C}$ to $75^{\circ} \mathrm{C} .84 \%$ of the activity of the immobilized SBU was retained after 25 cycles of use, and the activity was retained after 90 days at $4{ }^{\circ} \mathrm{C}$ [25].

The biocatalyst was prepared by immobilizing oenological commercial pectinase in calcium alginate hydrogels using a capture method, and its catalytic activity was evaluated under various storage conditions. The immobilization procedure did not change the optimal $\mathrm{pH}$ and temperature $\left(\mathrm{pH}=4.0\right.$ and $\left.20^{\circ} \mathrm{C}\right)$ for pectinase activity compared to the free enzyme. The captured pectinase exhibited activity up to six reaction cycles with a residual activity of $40 \%$. Storage stability studies have shown that pectinase trapped in a wet state retained its original enzymatic activity for up to 11 weeks, while lyophilized hydrogels retained their original activity after 8 months of storage. These results suggest that immobilized pectinase can be successfully used in various industrial applications, with particular emphasis on the grape juice clarification process. Thus, the turbidity of grape must was significantly reduced when using immobilized pectinase for $150 \mathrm{~min}$ at $20^{\circ} \mathrm{C}$. This biocatalyst can be easily removed after the clarification process and can be reused, minimizing the economic costs of production in the wine industry [26].

An interesting approach for encapsulating enzymes was proposed in Balabushevitch et al. [27], in which chymotrypsin was converted into a crystalline form by adding an excess concentration of sodium chloride (crystals from $0.1 \mu \mathrm{m}$ to $4 \mu \mathrm{m}$ ), followed by the deposition of polyelectrolyte layers to prevent degradation of the enzyme.

To create functional carriers (enzymes), one of the promising approaches is the formation of multicomponent microcapsules. The main advantage of multicomponent carriers is the ability to simultaneously encapsulate substances of different molecular weights or different degrees of hydrophobicity $[28,29]$.

The aim of the research is to obtain a complex enzyme preparation from pepsin and papain by sequential microencapsulation of enzymes in a pseudo-boiling layer and to evaluate its tenderizing effect on pork.

\section{Results and Discussion}

\subsection{Dependence of the Thickness of the Maltodextrin Layer on the Duration of Application to Pepsin}

It can be seen from the research results (Figure 1) that the thickness of the protective layer of the capsules $(\Delta)$ depends on the duration of processing $(\tau)$ of the enzymes in the microencapsulation apparatus.

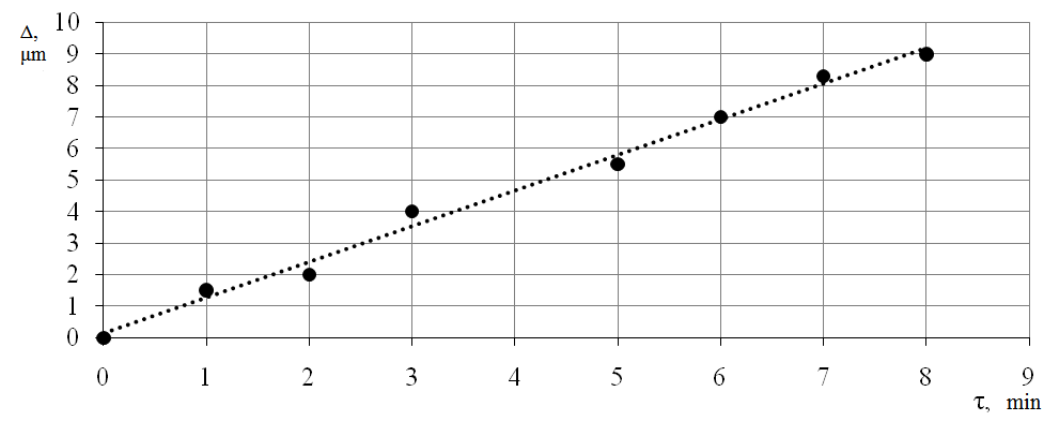

Figure 1. Dependence of the thickness of the maltodextrin layer on the duration of application to pepsin. 
A linear dependence ( $p \leq 0.05$; the number of measurements $n=10)$ was obtained for the average thickness of the application of the maltodextrin solution on the pepsin granule, depending on the duration of the application, which can be represented as the formula $y=1.1317 x+0.1358$. The value of the approximation reliability is close to 1 , which indicates the reliability of the trend line $\mathrm{R}^{2}=0.9918$. It was found that after $2 \mathrm{~min}$ of treatment with a maltodextrin solution, a protective surface layer $2 \mu \mathrm{m}$ thick is formed on the pepsin granule: after $6 \mathrm{~min}-6 \mu \mathrm{m}$, and after $8 \mathrm{~min}$ of treatment $-9 \mu \mathrm{m}$. In this case, the calculated speed of the air flow with the maltodextrin solution in the narrow section of the working chamber cone corresponded to the critical soaring speed of large pepsin particles and amounted to $0.17 \mathrm{~m} / \mathrm{s}$.

The author Menshutina [30] studied the change in the thickness of the applied coating depending on the time and conditions of the process, and presented photographs of the initial and encapsulated particles obtained by scanning electron microscopy. From the presented data, it can be seen that the coating of the particle is uniform; there are no gaps and cracks. The data obtained by us are consistent with the results of the research of Menshutina, which claims that the technology of encapsulation in a fluidized bed allows the application of coatings with a thickness of no more than $8 \mu \mathrm{m}$ on heat-sensitive materials, the particle size of which does not exceed $100 \mu \mathrm{m}$, without particle agglomeration. In this regard, it makes no sense to conduct research with the application of a protective layer above $8 \mu \mathrm{m}$.

Figure 2 shows samples of the enzyme pepsin at $\times 1500$ magnification before microencapsulation.

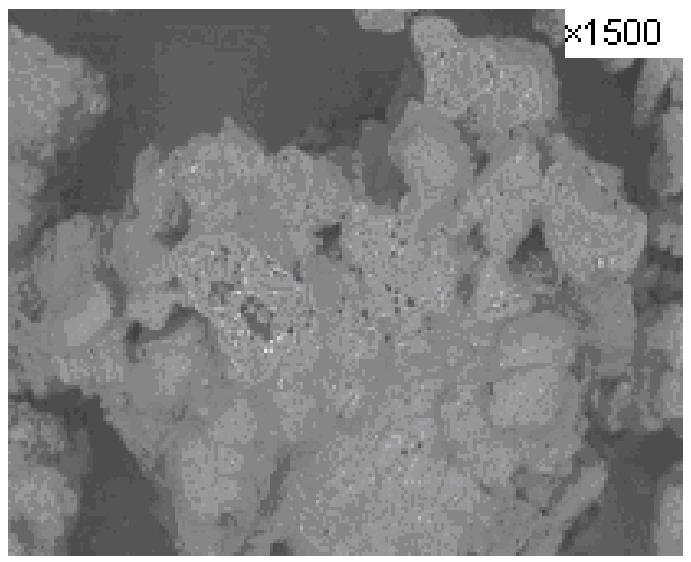

Figure 2. Samples of the pepsin enzyme before microencapsulation (magnification $\times 1500$ ).

Figure 3 shows the enzyme after encapsulation with a protective coating thickness of $6 \mu \mathrm{m}$.

The results of scanning electron microscopy (Figure 3) showed that the microcapsules of the pepsin enzyme acquire a more stable shape compared to the enzyme pepsin before microencapsulation (Figure 2) due to the formation of a protective layer (shown by the arrow in Figure 3). With this coating of the enzyme particles with a protective layer for 2 to $8 \mathrm{~min}$, the thickness of the coating varies in the range from 2 to $9 \mu \mathrm{m}$. This means that we can come to the conclusion that the thickness of microencapsulation with the enzyme maltodextrin can be regulated by the duration of application. So after 2 min of application, the layer thickness increases by $20 \%$, after $6 \mathrm{~min}$ by $70 \%$. 


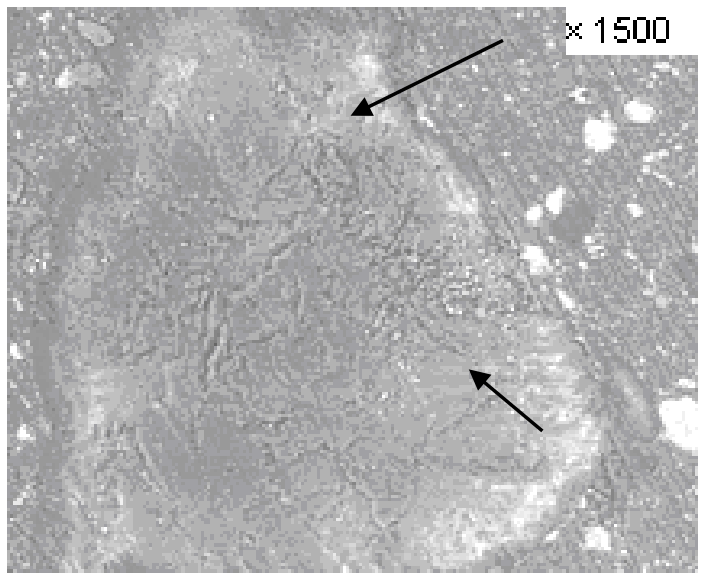

Figure 3. Enzyme pepsin after microencapsulation with a protective coating thickness of $6 \mu \mathrm{m}$ (magnification $\times 1500)$.

The obtained research results (Figures 2 and 3) are consistent with the data of Botinestean et al. [31], in which it has been established that spraying solutions of protective coatings makes it possible to obtain drops and particles of submicron size, as well as to spray them onto other particles. Since the cohesive and adhesive forces for supercritical solutions are small in comparison with these indicators for organic solvents, the force of capillary compression is also insignificant. This feature allows particles smaller than $100 \mu \mathrm{m}$ to be encapsulated in a fluidized bed without the formation of agglomerates. In this case, the supercritical fluid is used both as a solvent for the dispersible solution, and as a fluidizing agent for the coating, the particles are dried.

\subsection{Influence of the Thickness of the Pepsin Coating on Its Activity}

Figure 4 shows that the activity of pepsin depends on the thickness of the coating layer of the enzyme with maltodextrin. It was found that the thicker the maltodextrin layer, the higher the pepsin activity during the studied fermentation period. In this case, the activity of the enzyme is most stable with a layer thickness of $6 \mu \mathrm{m}$. As the thickness of the protective coating decreases, the enzyme loses its initial activity faster.

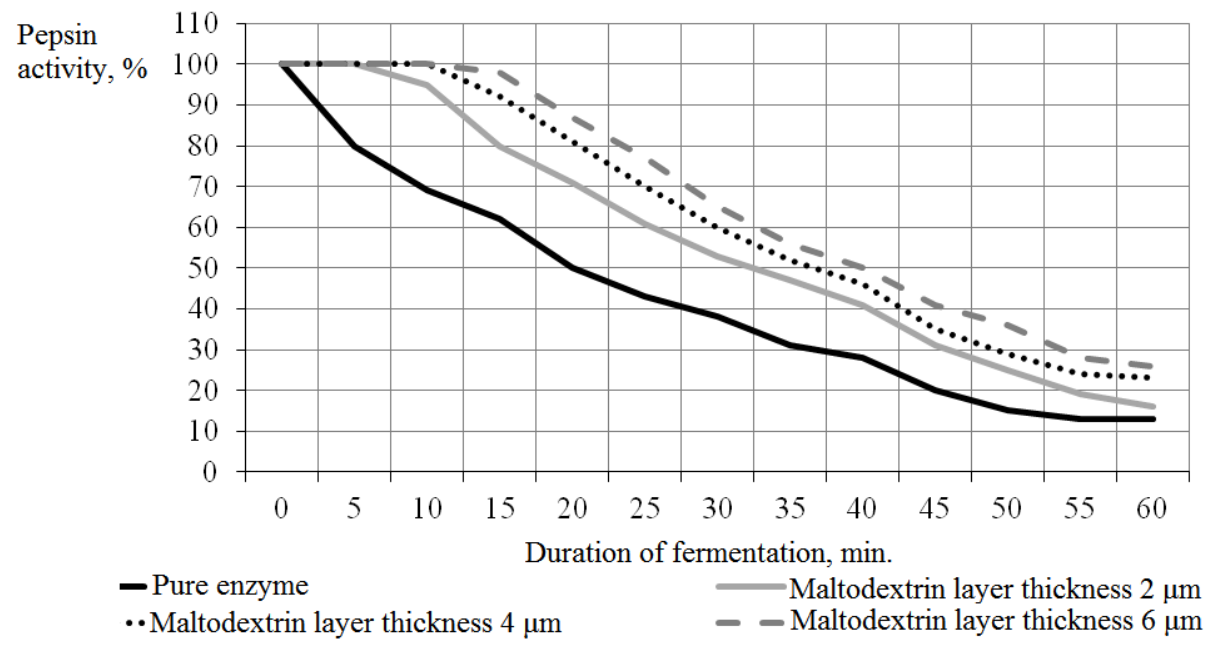

Figure 4. Influence of the thickness of the pepsin coating on its activity.

However, it should be noted that the activity of pepsin with a layer thickness of $4 \mu \mathrm{m}$ of maltodextrin is slightly lower than that of the enzyme with a coating thickness of $6 \mu \mathrm{m}$. In this regard, it is advisable to use an enzyme with a protective layer of maltodextrin with a thickness of $4 \mu \mathrm{m}$, as indicated by the statistical data presented in Table 1. 
Table 1. Statistical processing of the measurement results reflecting the effect of the thickness of the pepsin coating on its activity.

\begin{tabular}{ccc}
\hline Maltodextrin Layer Thickness, $\mu \mathrm{m}$ & Dispersion & Standard Deviation \\
\hline Pure enzyme & 708.49 & 26.62 \\
Maltodextrin layer thickness $2 \mu \mathrm{m}$ & 852.28 & 29.19 \\
Maltodextrin layer thickness $4 \mu \mathrm{m}$ & 830.56 & 28.82 \\
Maltodextrin layer thickness $6 \mu \mathrm{m}$ & 767.48 & 27.70 \\
\hline
\end{tabular}

\subsection{Dependence of Pepsin Activity on $\mathrm{pH}$ at a Coating Thickness of $4 \mu \mathrm{m}$ with Maltodextrin}

As can be seen from the data (Figure 5) $(p \leq 0.05$; the number of measurements $n=10)$, the maximum activity of immobilized pepsin shifts to the alkaline side, by about 2 units $\mathrm{pH}$, in comparison with a free enzyme, which, in all likelihood, may indicate the limitation of the diffusion of the substrate, when both the distribution of protons and the limitation of their diffusion are absent.

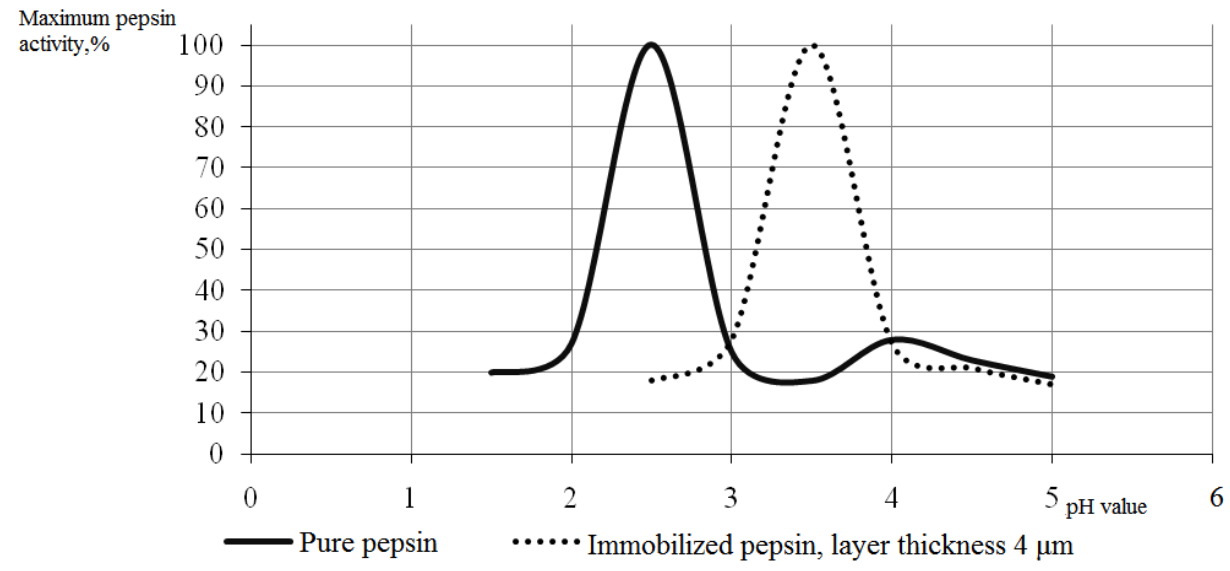

Figure 5. Dependence of pepsin activity on $\mathrm{pH}$ at a coating thickness of $4 \mu \mathrm{m}$ with maltodextrin.

A complex enzyme preparation from pepsin and papain was obtained by applying a protective coating with a thickness of $4 \mu \mathrm{m}$ from maltodextrin on pepsin, and then by applying papain, followed by applying a layer of maltodextrin $(4 \mu \mathrm{m})$ at an air flow velocity in a narrow section of the working chamber cone of $0.17 \mathrm{~m} / \mathrm{s}$.

\subsection{Dynamics of Pork $p H$ Depending on the Duration of Fermentation}

During the research, the physicochemical properties of pork were studied depending on the duration of fermentation. Table 1 shows the dynamics of the $\mathrm{pH}$ of pork samples depending on the duration of treatment with enzymes.

From the data in Table 2, it follows that under the action of the microencapsulated enzyme preparation (experiment 3 ), the greatest shift in $\mathrm{pH}$ to the alkaline side is noted, which is due to the accumulation of bases as a result of protein hydrolysis. Thus, after $36 \mathrm{~h}$ of fermentation, the $\mathrm{pH}$ value increased by $7.4 \%$. In meat samples, experiment 1 and experiment 2 , there were no significant changes in $\mathrm{pH}$.

\subsection{Dynamics of the Moisture-Binding Ability of Pork Samples Depending on the Duration of Fermentation}

The functional and technological properties of meat raw materials affecting the consistency and the output of the finished product are of great importance in meat products. Table 3 shows the dynamics of the moisture-binding ability of proteins pork depending on the duration of fermentation. 
Table 2. Dynamics of pork $\mathrm{pH}$ depending on the duration of fermentation.

\begin{tabular}{cccc}
\hline \multirow{2}{*}{ Fermentation Duration, $\mathbf{h}$} & \multicolumn{3}{c}{ pH Value ${ }^{*}$} \\
\cline { 2 - 4 } & Experiment 1 & Experiment 2 & Experiment 3 \\
\hline Before fermentation & $5.72 \pm 0,02$ & $5.72 \pm 0.02$ & $5.72 \pm 0.02$ \\
12 & $5.72 \pm 0,01$ & $5.72 \pm 0.01$ & $5.82 \pm 0.01$ \\
24 & $5.74 \pm 0,02$ & $5.76 \pm 0.02$ & $5.91 \pm 0.02$ \\
36 & $5.77 \pm 0,02$ & $5.79 \pm 0.01$ & $6.14 \pm 0.02$ \\
\hline
\end{tabular}

${ }^{*}$ Reliable at $p \geq 0.95$, the number of measurements $n=10$.

Table 3. Dynamics of the moisture-binding ability of pork samples depending on the duration of fermentation.

\begin{tabular}{cccc}
\hline \multirow{2}{*}{ Fermentation Duration, $\mathbf{h}$} & \multicolumn{2}{c}{ The Value of the Moisture-Binding Ability, \% * } \\
\cline { 2 - 4 } & Experiment $\mathbf{1}$ & Experiment 2 & Experiment 3 \\
\hline Before fermentation & $58.6 \pm 0.20$ & $58.5 \pm 0.22$ & $58.7 \pm 0.23$ \\
12 & $59.8 \pm 0.22$ & $59.7 \pm 0.20$ & $63.4 \pm 0.20$ \\
24 & $60.5 \pm 0.23$ & $60.4 \pm 0.21$ & $64.9 \pm 0.21$ \\
36 & $61.3 \pm 0.22$ & $61.8 \pm 0.25$ & $67.2 \pm 0.24$ \\
\hline
\end{tabular}

* Reliable at $p \geq 0.95$, the number of measurements $n=10$.

From the data in Table 3, it follows that salting pork with the use of a microencapsulated enzyme preparation in the brine composition to a greater extent increases the water-binding capacity of proteins in comparison with brine with pure enzymes. Thus, in meat samples (experiment 1), the water-binding capacity increased after $12 \mathrm{~h}$ by $2.05 \%$ compared to the control sample: after $24 \mathrm{~h}$-by $3.24 \%$, after $36 \mathrm{~h}$-by $4.61 \%$, while in meat samples of the second group-2.05\%; 3.25\%; $5.61 \%$ after 12,24 and $36 \mathrm{~h}$, respectively. The highest deviations were in the third group: after $12 \mathrm{~h}-$ by $8.01 \%$, after $24 \mathrm{~h}-$ by $10.56 \%$; after $36 \mathrm{~h}$-by $14.48 \%$. The increase in water-binding capacity is due to the formation of hydrophilic centers as a result of partial destruction of protein macromolecules under the action of enzymes.

\subsection{Dynamics of Solubility of Pork Proteins Depending on the Duration of Fermentation}

Table 4 shows the dynamics of the solubility of meat myofibrillar proteins depending on the duration of fermentation.

Table 4. Dynamics of solubility of pork proteins depending on the duration of fermentation.

\begin{tabular}{cccc}
\hline \multirow{2}{*}{ Fermentation Duration, $\mathbf{h}$} & \multicolumn{3}{c}{ The Amount of Nitrogen of Sarcoplasmic Proteins to the } \\
Total Nitrogen, \% * & \\
\cline { 2 - 4 } & Experiment $\mathbf{1}$ & Experiment 2 & Experiment 3 \\
\hline Before fermentation & $8.22 \pm 0.05$ & $8.21 \pm 0.04$ & $8.11 \pm 0.04$ \\
12 & $9.41 \pm 0.04$ & $9.63 \pm 0.05$ & $12.72 \pm 0.06$ \\
24 & $10.70 \pm 0.06$ & $10.92 \pm 0.05$ & $15.91 \pm 0.05$ \\
36 & $12.61 \pm 0.04$ & $12.82 \pm 0.04$ & $18.11 \pm 0.04$ \\
\hline
\end{tabular}

* Reliable at $p \geq 0.95$, the number of measurements $n=10$.

From the data in Table 4, it follows that the content of nitrogen of myofibrillar proteins to total nitrogen significantly increased in all studied meat samples. The highest deviation is observed in the third experiment. So, after $12 \mathrm{~h}$, the solubility of meat proteins increased by $56.79 \%$, after $24 \mathrm{~h}-$ by $96.30 \%$, after $36 \mathrm{~h}-123.46 \%$. In the first experiment, the solubility of proteins increased by $14.63 \%, 30.49 \%, 53.66 \%$ after $12,24,36 \mathrm{~h}$, respectively; in the second, by $17.07 \%, 32.93 \%, 56.10 \%$ after $12,24,36 \mathrm{~h}$ respectively. 


\subsection{Dynamics of Solubility of Sarcoplasmic of Myofibrillic Pork Proteins Depending on the Duration of Fermentation}

Table 5 shows the dynamics of the solubility of meat myofibrillar proteins depending on the duration of fermentation.

Table 5. Dynamics of solubility of sarcoplasmic of myofibrillic pork proteins depending on the duration of fermentation.

\begin{tabular}{cccc}
\hline \multirow{2}{*}{ Fermentation Duration, $\mathbf{h}$} & \multicolumn{3}{c}{ The Amount of Nitrogen of Myofibrillary Proteins to the } \\
Total Nitrogen, \% * & \\
\cline { 2 - 4 } & Experiment 1 & Experiment 2 & Experiment 3 \\
\hline Before fermentation & $15.11 \pm 0.04$ & $15.12 \pm 0.03$ & $15.21 \pm 0.04$ \\
12 & $15.42 \pm 0.05$ & $15.64 \pm 0.04$ & $17.72 \pm 0.03$ \\
24 & $16.30 \pm 0.06$ & $16.40 \pm 0.05$ & $18.54 \pm 0.04$ \\
36 & $16.91 \pm 0.04$ & $17.11 \pm 0.04$ & $20.80 \pm 0.05$ \\
\hline
\end{tabular}

${ }^{*}$ Reliable at $p \geq 0.95$, the number of measurements $n=10$

From the data in Table 5, it follows that the nitrogen content of myofibril proteins in relation to the total nitrogen significantly increased in all studied meat samples. The greatest manifestation of a positive tendency to increase is manifested in 3 experiments, so an increase in the nitrogen content occurred after $12 \mathrm{~h}$ by $16.45 \%$ compared to the control sample; after $24 \mathrm{~h}$-by $21.71 \%$, after $36 \mathrm{~h}$-by $36.84 \%$. Then, as in the first experiment, by $1.99 \%, 7.95 \%, 11.92 \%$, in the second experiment, by $3.31 \%, 8.61 \%, 13.25 \%$ after $12,24,36 \mathrm{~h}$, respectively.

\subsection{Dynamics of Accumulation of Non-Protein Nitrogen Depending on the Duration of Fermentation}

As our studies have shown, non-protein nitrogen accumulates during fermentation (Table 6), which indicates a partial proteolysis of protein macromolecules.

Table 6. Dynamics of accumulation of non-protein nitrogen depending on the duration of fermentation.

\begin{tabular}{cccc}
\hline \multirow{2}{*}{ Fermentation Duration, $\mathbf{h}$} & \multicolumn{3}{c}{ Non-Protein Nitrogen to Total Nitrogen, \% * } \\
\cline { 2 - 4 } & Experiment $\mathbf{1}$ & Experiment 2 & Experiment 3 \\
\hline Before fermentation & $5.72 \pm 0.03$ & $5.72 \pm 0.02$ & $5.72 \pm 0.02$ \\
12 & $6.13 \pm 0.04$ & $6.31 \pm 0.03$ & $7.94 \pm 0.03$ \\
24 & $6.45 \pm 0.02$ & $6.72 \pm 0.01$ & $8.93 \pm 0.04$ \\
36 & $6.81 \pm 0.02$ & $7.11 \pm 0.04$ & $10.53 \pm 0.02$ \\
\hline
\end{tabular}

${ }^{*}$ Reliable at $p \geq 0.95$, the number of measurements $n=10$

From the data obtained, it can be seen that when pork is treated with a microencapsulated complex enzyme preparation, the greatest increase in non-protein nitrogen is observed. Thus, in experiment 3, the percentage of non-protein nitrogen to total nitrogen increased after 12, 24 and $36 \mathrm{~h}$ of fermentation at $38.60 \%, 56.14 \%$ and $84.21 \%$ compared with the control sample; in the first, by $7.02 \%, 12.28 \%$ and $19.30 \%$, in the second, by $10.52 \%$, $17.54 \%$ and $24.56 \%$.

The data obtained are consistent with Thomson's studies [32], which proved that enzymatic hydrolysis changes the physicochemical properties of proteins. The higher the degree of hydrolysis, the more the properties of the hydrolyzable protein substrate change. The molecular weight distribution of peptides in the hydrolyzate, which depends on the specificity of proteolytic processes, determines the properties of the hydrolyzate such as taste, osmolality, antigenicity, adsorption kinetics, and a number of other important properties. During protein hydrolysis, its emulsifying, moisture-binding properties and solubility are improved [33].

In our study, primary hydrolysis is observed, causing the cleavage of less than $10 \%$ of peptide bonds, thus causing an improvement in the functional and technological properties 
of proteins, which is very important in the production of meat products. These data are confirmed by Jeewanthi's studies [34], which found that enzymatic hydrolysis increases the degree of protein hydration, which is important for many types of food. Deeper hydrolysis leads to a loss of emulsifying properties, but increases the solubility of hydrolysis products, making them resistant to precipitation by high temperatures, acids and metal ions.

\subsection{Dependence of the Proteolytic Activity of Pure Enzymes and Microencapsulated Complex Enzyme Preparation on the Duration of Storage}

The effect of storage time at $0-2{ }^{\circ} \mathrm{C}$ on the activity of pure enzymes and microencapsulated complex preparation of pepsin and papain has been studied. The results obtained showed (Figure 6) that the immobilization of enzymes stabilizes the activity practically within 6 months, while the activity of pure (free) enzymes decreases after 3 months. As can be seen from this figure, the complex enzyme preparation exhibits high proteolytic activity for 6 months storage.

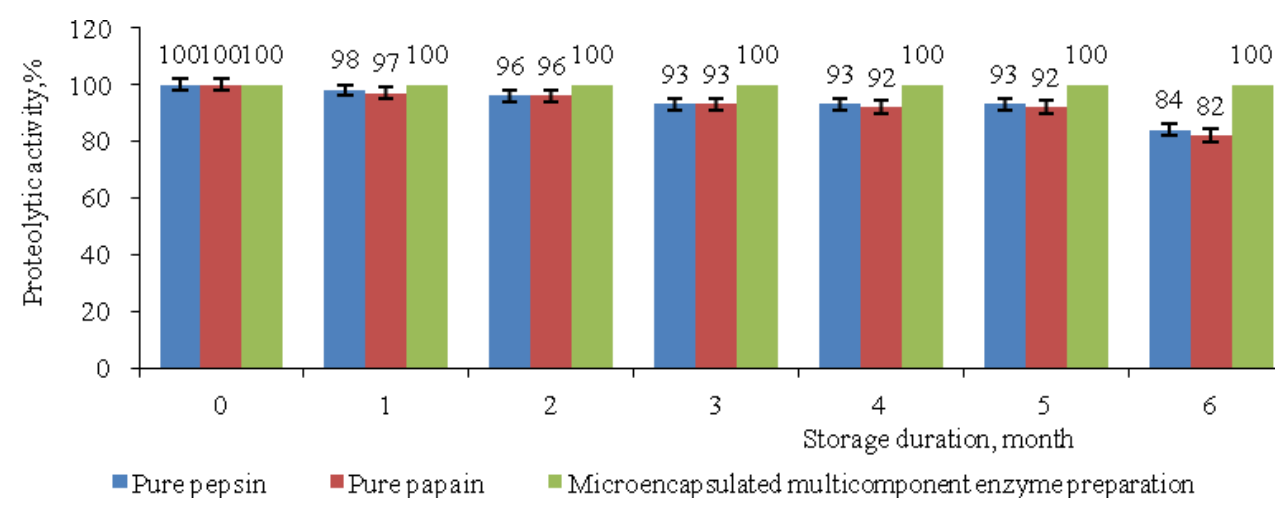

Figure 6. Dependence of the proteolytic activity of pure enzymes and microencapsulated complex enzyme preparation on the duration of storage.

The research results showed that the microencapsulated complex enzyme preparation enhances the processes of protein hydrolysis with the formation of free amino acids and peptides. The presented data show the high efficiency of sequential microencapsulation of the enzyme pepsin and then papain in a protective layer of maltodextrin in order to preserve their activity during storage.

The research results are consistent with the results obtained by Baumler and Georgieva [35]. Researchers Kuiper et al. [36] have formed structures of the "matryoshka" type with two concentric carriers. The microcapsule volumes were independently filled with macromolecules, which were separated by a protective coating. Subsequent studies have shown that controlled triggering of an enzymatic reaction works. Later, three enzymes were encapsulated in concentric multicomponent microparticles of calcium carbonate and an enzymatic reaction was carried out. It was found that the kinetics of the enzymatic reaction depends on the distance between the components.

2.10. Influence of the Duration of Storage of Pure Pepsin, Pure Papain and Microencapsulated Complex Enzyme Preparation on the Structural and Mechanical Properties of Ham

Figure 7 shows the effect of the storage time of pure pepsin, pure papain and microencapsulated complex enzyme preparation on the structural and mechanical properties of ham. 


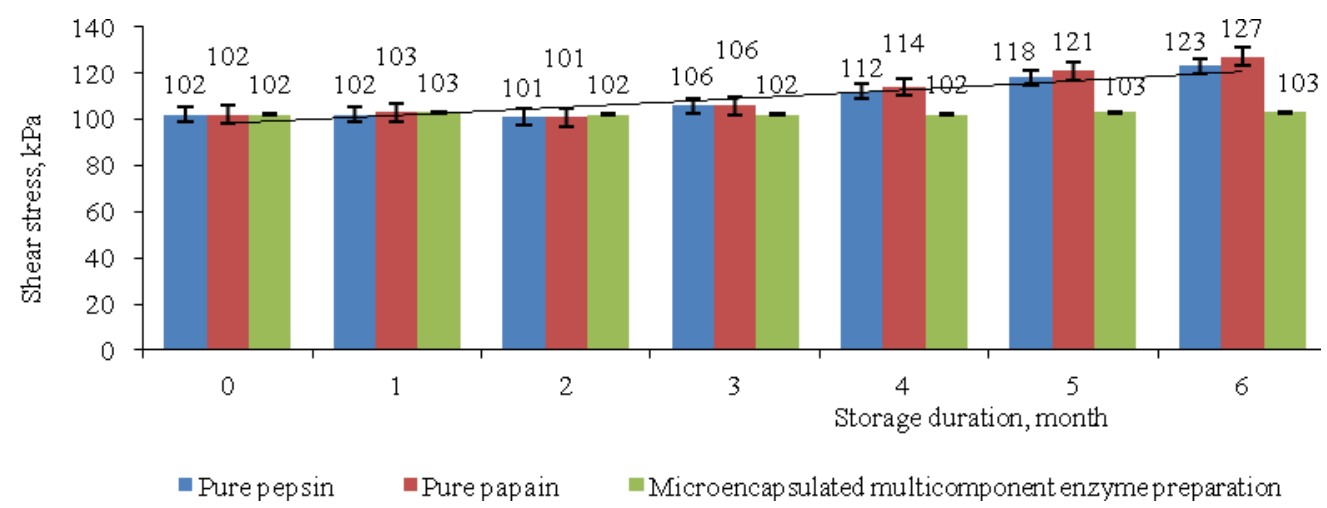

Figure 7. Influence of the duration of storage of pure pepsin, pure papain and microencapsulated complex enzyme preparation on the structural and mechanical properties of ham.

It was found that within 3 months storage, the proteolytic effect of pure enzymes remained practically at the same level, which can be seen from the results of determining the shear stress of pork. However, it can be seen that after 3 months storage, these enzymes noticeably lost their activity, as a result of which their proteolytic effect was significantly reduced. At the same time, the microencapsulated complex enzyme preparation retained its activity for 6 months storage, which can be seen from the results of determining the value of the shear stress. These data may indicate the protective effect of maltodextrin, which prevents the inactivation of pepsin and papain, and confirm the results of determining the activity of pure enzymes and microencapsulated multicomponent enzyme preparation (Figure 7).

The data obtained are consistent with the studies of Minaev [37], where an increase in protein breakdown products in meat model systems was proved. Test samples of raw meat were injected with brine containing a proteolytic enzyme, left for $48 \mathrm{~h}$ at $8{ }^{\circ} \mathrm{C}$, and the accumulation of protein degradation products was investigated. Then, the samples were cooked at $80^{\circ} \mathrm{C}$ for $50 \mathrm{~min}$. In determining the maximum shear stress and microstructural characteristics, the effectiveness of tenderization in the processing of meat with enzymes has been proven.

\section{Materials and Methods}

\subsection{The Objects of Research}

The objects of research were enzymes: pepsin activity-300,000 units, manufacturer Meito Sangyo Co., Ltd. (Nagoya, Japan) and papain activity 10,000 units, manufacturerZhejiang Cathaya International Co., Ltd. (Hangzhou, China), which were microencapsulated into a protective coating of maltodextrin.

\subsection{Research Materials}

The studies were conducted on a boneless hind quarter of chilled low-fat pork. Control samples of ham were injected with brine in the amount of $15 \%$ to the mass of raw materials with a density of $1100 \mathrm{~kg} / \mathrm{m}^{3}$, containing nitrite salt in the amount of $14 \%$, sugar $1 \%$ and pure enzyme pepsin in the amount of $0.15 \%$ (experiment 1 ). In experiment 2 , ham samples were injected with the same brine containing pure papain enzyme in an amount of $0.15 \%$. In experiment 3 , the hams were syringed with brine containing a microencapsulated enzyme complex consisting of pepsin and papain in an amount of $0.15 \%$.

\subsection{Microencapsulation Apparatus}

Microencapsulation was carried out in a specially designed apparatus by applying a fluidized bed (FB) to the surface of the enzyme (Figure 8). 


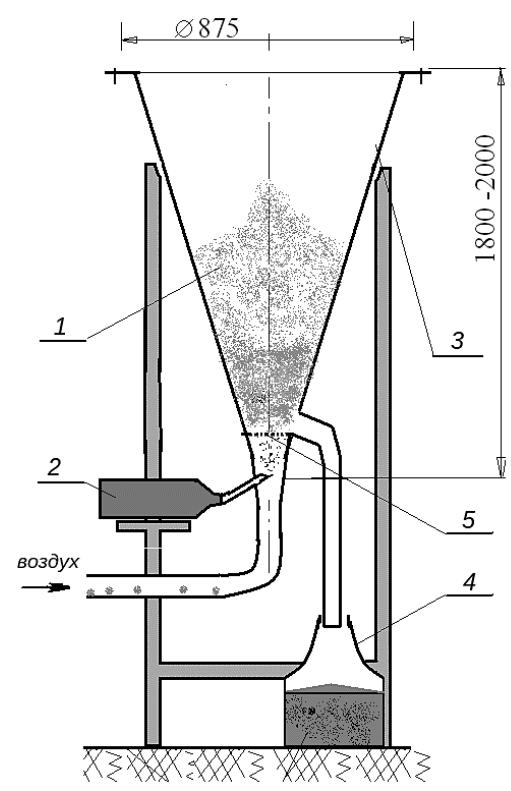

Figure 8. Schematic diagram of microencapsulation.

(1) Bulk material; (2) Disperser of liquid material; (3) the body of the conical body; (4) Container with coated bulk material (microcapsules); (5) Porous partition.

The pepsin enzyme is poured into a conical body with an upward expansion of 3 (the cone dimensions allow coating different sized particles and eliminating their entrainment). Air is supplied to the lower part of the device by a fan. By changing the fan supply voltage, the air velocity is set, which ensures the formation of the $\mathrm{FB}$ of the required height. After that, the liquid component dispersant 2 is turned on. The liquid component $(10 \%$ maltodextrin solution) is fed into the air duct in the form of a mist. Passing through the porous partition 5 , it enters the FB of the coated pepsin. Due to the chaotic movement in the FB, a uniform coating of the surfaces of pepsin particles occurs. This process is intensive and is also accompanied by the beginning of drying on the surface of the particles due to gushing air flows washing them from all sides. After dispersing the required amount of liquid material and drying, the air supply stops, and the microcapsules of the finished material are poured into the container 4 .

\subsection{The Composition of the Protective Layer}

A $10 \%$ aqueous solution of maltodextrin obtained by the enzymatic method from corn starch as a result of its partial hydrolysis and an equivalent mass of dextrose was used as a protective layer. When heated to $100{ }^{\circ} \mathrm{C}$ and at a $\mathrm{pH}$ of $4.0-5.0$, corn starch breaks down, resulting in maltodextrin and corn syrup. The ratio of solid to liquid (S/L) ranged from 10:1 to 11.5:1. The fluidizing agent, including in the drying mode, was air at room temperature, pumped through the apparatus. Pure unencapsulated pepsin (free pepsin) and papain were used as controls.

\subsection{Storage of Enzymes and Enzyme Preparation}

Pure enzymes and a complex enzyme preparation were stored packed in a dry, protected from light in a room at a temperature not exceeding $2{ }^{\circ} \mathrm{C}$ and a relative air humidity not exceeding $75 \%$ in accordance with GOST R 52688-2006. The shelf life of pure enzymes and enzyme preparation did not exceed 10 months.

\subsection{Methods for Determining the Thickness of a Protective Layer}

The thickness of the protective layer of maltodextrin on the enzyme was determined by electron microscopy at high magnifications, and for X-ray spectral microanalysis, the polished samples were examined using a JSM 6490LV (manufacturer, Jeol Ltd. (Tokyo, Japan)) scanning electron microscope. 


\subsection{Methods for Determining the Proteolytic Activity of Enzymes}

The proteolytic activity of enzymes was determined according to GOST 34430-2108. Casein was used as a substrate according to Hamersten according to the method of M. L. Anson. The amount of tyrosine was determined spectrophotometric method on an SF-46 spectrophotometer at a wavelength of $280 \mathrm{~nm}$ (Joint-stock company LOMO, Russia, St. Petersburg).

\subsection{Methods for the Determination of Protein Hydrolysis}

The degree of protein hydrolysis was studied by determining the amine and total nitrogen. Amine nitrogen was determined according to GOST R 55479-2013. Total nitrogen, by the Kjeldahl method. Solubility of muscle tissue proteins, by sequential extraction of sarcoplasmic and myofibrillar proteins according to the method described by Zhuravskaya [38].

\subsection{Determination of Non-Protein Nitrogen}

Non-protein nitrogen (the sum of nitrogen, polypeptides and other nitrogenous compounds) was determined in the mineralized filtrate after precipitation of proteins with trichloroacetic acid.

\section{Conclusions}

The results obtained showed that the biocatalytic activity of a complex enzyme preparation obtained by sequential microencapsulation of pepsin and papain in a protective shell made of maltodextrin is higher compared to pure enzymes. Microencapsulation allows maintaining the high proteolytic activity of enzymes for a long storage period.

It has been shown that the thickness of the protective layer during microencapsulation of pepsin and papain in the pseudo-boiling layer of maltodextrin may not exceed 4-6 microns. It was found that the maximum activity of immobilized enzymes is shifted to the alkaline side.

Based on the data obtained, it is possible to recommend microencapsulation of the proteolytic enzymes of pepsin and papain using maltodextrin, which will expand the possibilities of using immobilized enzymes in the production of meat products.

Author Contributions: Conceptualization, S.L.T., N.V.T., L.S.K., O.A.K., I.N.T. and N.V.M.; methodology, S.L.T., N.V.T., L.S.K., O.A.K., I.N.T. and N.V.M.; software, S.L.T., N.V.T., L.S.K., O.A.K., I.N.T. and N.V.M.; validation, N.V.M.; formal analysis, N.V.M.; investigation, S.L.T., N.V.T., L.S.K. and O.A.K.; resources, I.N.T.; data curation, I.N.T.; writing-original draft preparation, S.L.T., N.V.T., L.S.K., O.A.K. and I.N.T.; writing-review and editing, N.V.M.; visualization, N.V.M.; supervision, S.L.T.; project administration, N.V.M.; funding acquisition, S.L.T. All authors have read and agreed to the published version of the manuscript.

Funding: This research received no external funding.

Conflicts of Interest: The authors declare no conflict of interest.

\section{References}

1. Charmpi, C.; Vervaet, T.; Reckem, E.V.; Geeraerts, W.; Veken, D.V.D.; Ryckbosch, W.; Leroy, F.; Brengman, M. Assessing levels of traditionality and naturalness depicted on labels of fermented meat products in the retail: Exploring relations with price, quality and branding strategy. Meat Sci. 2021, 181, 108607. [CrossRef] [PubMed]

2. Ahangari, H.; Yazdani, P.; Ebrahimi, V.; Soofiyani, S.R.; Azargun, R.; Tarhriz, V.; Eyvazi, S. An Updated review on production of food derived bioactive peptides; focus on the psychrotrophic bacterial proteases. Biocatal. Agric. Biotechnol. 2021, $35,102051$. [CrossRef]

3. Antipova, L.V.; Gorbunkov, M.V. Physicochemical and biocatalytic properties of the proteolytic complex of the drug "Protepsin". Bull. Voronezh State Univ. Eng. Technol. 2016, 1, 89-93.

4. Santos, J.M.D.; Ignácio, E.O.; Bis-Souza, C.V.; Silva-Barretto, A.C.D. Performance of reduced fat-reduced salt fermented sausage with added microcrystalline cellulose, resistant starch and oat fiber using the simplex design. Meat Sci. 2021, 175, 108433. [CrossRef] 
5. Dwivedi, P.; Sharma, A.K.; Singh, S.P. Biochemical properties and repression studies of an alkaline serine protease from a haloalkaliphilic actinomycete, Nocardiopsisdassonvillei subsp. albirubida OK-14. Biocatal. Agric. Biotechnol. 2021, 35 , 102059. [CrossRef]

6. El-Ghonemy, D.H.; Ali, T.H. Effective bioconversion of feather-waste Keratin by Thermo-Surfactant Stable Alkaline Keratinase produced from Aspergillus sp. DHE7 with promising biotechnological application in detergent formulations. Biocatal. Agric. Biotechnol. 2021, 35, 102052. [CrossRef]

7. Naqvi, Z.B.; Campbell, M.A.; Latif, S.; Thomson, P.C.; McGill, D.M.; Warner, R.D.; Friend, M.A. Improving tenderness and quality of M. biceps femoris from older cows through concentrate feeding, zingibain protease and sous vide cooking. Meat Sci. 2021, 180, 108563. [CrossRef]

8. Chanalia, P.; Gandhi, D.; Attri, P.; Dhanda, S. Extraction, purification and characterization of low molecular weight Prolineiminopeptidase from probiotic L. plantarum for meat tenderization. Int. J. Biol. Macromol. 2018, 109, 651-663. [CrossRef]

9. Makhova, A.A.; Minaev, M.Y.; Kulikovsky, A.V.; Vostrikova, N.L. Study of the enzymatic activity of recombinant metallopeptidase intended for use in the meat industry. Quest. Nutr. 2019, 88, 95-104. [CrossRef]

10. Ribeiro, W.O.; Ozaki, M.M.; Santos, M.D.; Rodríguez, A.P.; Pflanzer, S.B.; Pollonio, M.A.R. Interaction between papain and transglutaminase enzymes on the textural softening of burgers. Meat Sci. 2021, 174, 108421. [CrossRef]

11. Sun, Q.; Chen, F.; Geng, F.; Luo, Y.; Gong, S.; Jiang, Z. A novel aspartic protease from Rhizomucormiehei expressed in Pichia pastoris and its application on meat tenderization and preparation of turtle peptides. Food Chem. 2017, 245, 570-577. [CrossRef]

12. Brazzelli, M.; Cruickshank, M.; Tassie, E.; McNamee, P.; Robertson, C.; Elders, A.; Fraser, C.; Hernandez, R.; Lawrie, D.; Ramsay, C. Collagenase clostridium histolyticum for the treatment of Dupuytren's contracture: Systematic review and economic evaluation. Health Technol. Assess. 2015, 19, 201-202. [CrossRef]

13. Kudryashov, L.S.; Uzakov, Y.M.; Tikhonov, S.L.; Tikhonova, N.V.; Diachkova, A.V. Microencapsulation of proteolytic en-zymes for industrial application. News Natl. Acad. Sci. Repub. Kazakhstan. Ser. Geol. Tech. Sci. 2020, 3, 161-169.

14. Smaoui, S.; Hlima, H.B.; Braiek, O.B.; Ennouri, K.; Mellouli, L.; Khaneghah, A.M. Recent advancements in encapsulation of bioactive compounds as a promising technique for meat preservation. Meat Sci. 2021, 181, 108585. [CrossRef] [PubMed]

15. Beck, P.H.B.; Matiucci, M.A.; Neto, A.A.M.; Feihrmann, A.C. Sodium chloride reduction in fresh sausages using salt encapsulated in carnauba wax. Meat Sci. 2021, 175, 108462. [CrossRef] [PubMed]

16. Graily-Moradi, F.; Hejazi, M.J.; Enayati, A.A.; Hamishehkar, H. Evaluation of co-nanoencapsulation process on the toxicity and biochemical metabolism of imidacloprid and lambda-cyhalothrin in Myzuspersicae (Sulzer). Biocatal. Agric. Biotechnol. 2021, 33, 101974. [CrossRef]

17. Homayouni-Rad, A.; Mortazavian, A.M.; Mashkani, M.G.; Hajipour, N.; Pourjafar, H. Effect of Alyssum homolocarpum mucilage and inulin microencapsulation on the survivability of Lactobacillus casei in simulated gastrointestinal and high-temperature conditions. Biocatal. Agric. Biotechnol. 2021, 35, 102075. [CrossRef]

18. Stella, M.; Theeba, M.; Illani, Z.I. Organic fertilizer amended with immobilized bacterial cells for extended shelf-life. Biocatal. Agric. Biotechnol. 2019, 20, 101248. [CrossRef]

19. Bahgat, F.; Hoda, S.E.; Amira, A.; Amal, M.H.; Nayra, S.H.M. The application of multi-particulate microcapsule containing probiotic bacteria and inulin nanoparticles in enhancing the probiotic survivability in yoghurt. Biocatal. Agric. Biotechnol. 2019, 22, 101391. [CrossRef]

20. Shaymaa, A.I.; Mohamed, E.H.; Amal, M.H. Single step hydrolysis of chitin using thermophilic immobilized exochitinase on carrageenan-guar gum gel beads. Biocatal. Agric. Biotechnol. 2019, 21, 101281. [CrossRef]

21. Wahba, M.I. Carrageenan stabilized calcium pectinate beads and their utilization as immobilization matrices. Biocatal. Agric. Biotechnol. 2021, 35, 102078. [CrossRef]

22. Weber, D.; Nascimento, M.d.G.; Parize, A.L. Immobilization of Burkholderiacepacia lipase on cross-linked chitosan-based support for the synthesis of geranyl acetate. Biocatal. Agric. Biotechnol. 2019, 19, 101133. [CrossRef]

23. Navya, A.; Mohanan, P.V. Template synthesized polypyrroles as a carrier for diastase alpha amylase immobilization. Biocatal. Agric. Biotechnol. 2019, 19, 101164. [CrossRef]

24. Hala, R.W.; Mohamed, A.A.; Heba, M.E.; Hanan, F.Y. Nanoporous Zeolite-X as a new carrier for laccase immobilization and its application in dyes decolorization. Biocatal. Agric. Biotechnol. 2019, 19, 101135. [CrossRef]

25. Bracco, L.F.; Levin, G.J.; Urtasun, N.; Cañizo, A.A.N.D.; Wolman, F.J.; Miranda, M.V.; Cascone, O. Covalent immobilization of soybean seed hull urease on chitosan mini-spheres and the impact on their properties. Biocatal. Agric. Biotechnol. 2019, 18, 101093. [CrossRef]

26. Martín, M.C.; López, O.V.; Ciolino, A.E.; Morata, V.I.; Villar, M.A.; Ninago, M.D. Immobilization of enological pectinase in calcium alginate hydrogels: A potential biocatalyst for winemaking. Biocatal. Agric. Biotechnol. 2019, 18, 101091. [CrossRef]

27. Balabushevitch, N.G.; Sukhorukov, G.B.; Moroz, N.A.; Volodkin, D.V.; Larionova, N.I.; Donath, E.; Mohwald, H. Encapsulation of proteins by layer-bylayer adsorption of polyelectrolytes onto protein aggregates: Factors regulating the protein release. Biotechnol. Bioeng. 2001, 76, 207-213. [CrossRef]

28. Vergaro, V.; Baldassarre, F.; De Santis, F.; Ciccarella, G.; Giannelli, G.; Leporatti, S. TGF-Beta Inihibitor-loaded Polyelectrolyte Multilayers Capsules for Sustained Targetingof Hepatocarcinoma Cells. Curr. Pharm. Des. 2012, 18, 4155-4164. [CrossRef] [PubMed] 
29. Chandrawati, R.; Van Koeverden, M.P.; Lomas, H.; Caruso, F. Multicompartment particle assemblies for bioinspired encapsulated reactions. J. Phys. Chem. 2011, 2, 2639-2649. [CrossRef]

30. Menshutina, N.V. Technologies of incapsulation. Pharm. Technol. 2014, 9, 30-33.

31. Botinestean, C.; Hossain, M.; Mullen, A.M.; Kerry, J.P.; Hamill, R.M. The influence of the interaction of sous-vide cooking time and papain concentration on tenderness and technological characteristics of meat products. Meat Sci. 2021, 177, 108491. [CrossRef] [PubMed]

32. Thomson, R.L.; Buckley, J.D. Protein hydrolysates and tissue repair. Nutr. Res. Rev. 2011, 24, 191-197. [CrossRef] [PubMed]

33. Sviridenko, Y.Y.; Myagkonosov, D.S.; Abramov, D.V.; Ovchinnikova, E.G. Scientific and methodological approaches to the development of technology of protein hydrolysates for special nutrition. Part 2. Functional properties of protein hydrolysates depending on the specificity of proteolytic processes. Food Ind. 2017, 6, 50-53.

34. Jeewanthi, R.K.C.; Lee, N.K.; Paik, H.D. Improved functional performance of whey protein hydrolysates in the food industry. Korean J. Food Sci. Anim. Resour. 2015, 35, 350-359. [CrossRef] [PubMed]

35. Bäumler, H.; Georgieva, R. Coupled Enzyme Reactions in Multicompartment Microparticles. Biomacromolecules 2010, 11, 1480-1487. [CrossRef]

36. Kuiper, S.M.; Nallani, M.; Vriezema, D.M.; Cornelissen, J.J.L.M.; van Hest, J.C.M.; Nolte, R.J.M.; Rowan, A.E. Enzymes containing porous polymersomes as nano reaction vessels for cascade reactions. Org. Biomol. Chem. 2008, 6, 4315-4318. [CrossRef]

37. Minaev, M.Y.; Makhova, A.A. Possibility of using recombinant metallopeptidase M9 for tenderizing meat. Food Ind. 2019, 4, 63-64.

38. Zhuravskaya, N.K. Research and Quality Control of Meat and Meat Products; Agropromizdat: Moscow, Russia, 1985. 